International Journal of Educational Studies

ISSN: 2641-533X

Vol. 4, No. 4, pp. 144-153.

2021

DOI: $10.53935 / 2641-533 x . v 4 i 4.166$

(C) 2021 by the authors; licensee Academic Publishing Group

\title{
Thorns amongst Roses? Lived Experience of Philippine Male College Students Aspiring to Become Professional Elementary Teachers
}

\author{
Michael B. Cahapay: College of Education, Mindanao State University, General Santos City, Philippines.
}

\begin{abstract}
There is a noticeable under-representation of the male gender particularly in the field of elementary teacher education. The main aim of this paper is to understand the lived experience of male college students aspiring to become professional elementary teachers. As phenomenological research, it involved six purposively selected male students enrolled in a predominantly female elementary teacher education program in a Philippine university. The data were gathered through online interviews and analyzed based on a phenomenological analysis framework. The following themes emerged: 1.) We hear discouraging stereotypes about teaching; 2.) We are passionate about educating the young ones; 3.) We feel that awkward moment in a room of females; and 4.) We have an inclusive learning environment. These themes are based on the individual textural and structural descriptions and form the basis for the composite textural and structural descriptions of the phenomenon of interest. This paper confirms the experiences encountered by males in the formal teaching career stage as relative to experiences received by males in the early stage of the teacher preparation. It also identifies factors that encourage males to enter elementary teacher education as a field of study, providing practical insights for designing a more inclusive program.
\end{abstract}

Key words: Lived experience, Male student, Elementary education, Teacher education, Gender, Philippines.

\section{Introduction}

Occupation in many societies is noticeably characterized by a gender division of labor. This division is expressed in which tasks are assigned to the individuals based on their gender (Reskin, 2001). Where gender division of labor is high, it is further exacerbated by discriminatory perceptions and practices (Baunach, 2002). This division is extended to formal fields of studies, especially in higher education. According to International Labor Organization (2008) education is also separated along gender lines, with distinctions between regions and cultures. For example, in the occupation of scientists, most are males, which can be also mirrored in the way science studies is perceived as a male domain (Makarova, Aeschlimann, \& Herzog, 2019).

Despite movements calling for more balance of gender in different occupations (Cushman, 2006) there is one occupation where males noticeably form the group of minorities. The occupation of teaching the children has traditionally been dominated by females. According to Drudy (2008) this phenomenon can be traced to issues related to economic growth and development, social and cultural views on gender, and the value of children and rearing practices. Through the years, Schmude and Jackisch (2019) have observed that there has been a feminization of the teaching profession. As a result, the norm for the occupation of teaching has usually excluded the males. This marginalization creates a concern, then, for males who have professional aspirations in the occupation of teaching.

Within the occupation of teaching, there is further a gender marginalization of males especially in the field of elementary teaching (Bittner \& Cooney, 2001). Most males who foray into the occupation of 


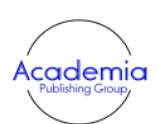

International Journal of Educational Studies

Volume 4, Issue 4, pp. 144-153

2021

DOI: $10.53935 / 2641-533 x . v 4 i 4.166$

Email: mbcahapay@up.edu.ph

Funding: This study received no specific

financial support.

Article History:

Received: 19 October 202

Revised: 11 November 2021

Accepted: 2 December 2021

Published: 21 December 2021

(C) 2021 by the authors: licensee Academic

Publishing Group elementary teaching are placed under some scrutiny by the people in society (Williams, 1992). They become victims of the unfounded stereotype that males lack the caring ability that is needed to teach children at the elementary level (Henry, 2012). There further continues a misjudgment that males should teach at the secondary level, a somewhat higher position affirmed by social norms (Skelton, 2003). Another unfavorable assumption is that males who want to work with elementary children may be predators, homosexuals, or effeminate (Meader, 2017). These biases may prevent males from taking the path of elementary teaching.

The Philippine society appears to perceive elementary teacher education and elementary teaching as fields of females. As mentioned by Regalado (2017) census data show that more women are enrolled in education courses and there are more female teachers. She cited that specifically in the culled data for the school year 2008-2009, there were $89.58 \%$ females while only $10.42 \%$ males in the occupation of elementary teaching. With this, Bongco and Abenes (2019) affirmed that feminization in the Philippine teaching profession is an extant issue that promotes gender inequality and exclusion. Despite this issue, however, there is little that is known locally about the minoritized group of males in the domains of elementary teacher education and elementary teaching.

Considering these typically negative perceptions, there is an emerging body of scholarly works (Garcia, 2014; Henry, 2012; Richardson, 2011; Schurman, 2015; Walker, 2012; Williams, 2012) that have attempted to particularly explore the "lived experience" of males in their elementary teaching career stage. However, the lived experience of males specifically in their elementary teacher preparation stage has not been well explored. Other related studies are either not conceptually set in the elementary teacher preparation stage (e.g. Shouldice (2013)) or not methodologically focused on the lived experiences (e.g. (Greger, 2014; Henry, 2012)). Addressing these important conceptual and methodological gaps, this current paper is carried out as phenomenology research aimed at understanding the lived experiences of males in their elementary teacher preparation stage.

This present study focuses on the teacher preparation stage because this point appears crucial in identity development. Some researchers contend that students have not developed professional teacher identity at this stage but a student identity (Flores \& Day, 2006; Levin \& He, 2008). Given this situation, it is interesting to explore how gender intersects the ongoing teacher identity development from the lens of the marginalized segment of males. Moreover, phenomenology is selected as a method because it is distinctly positioned to help scholars understand the phenomenon. The outcome of phenomenology widens knowledge about a certain phenomenon such as emerging issues related to gender (e.g., see (Anjum, Kamal, \& Bilwani, 2019; Powers, Herron, Sheeler, \& Sain, 2018)) through the lived experience. Considering this cause, phenomenology is well suited to gain insights as regards lived experiences arising in a preparation program traditionally considered atypical for males.

Thus, this paper aims to understand the lived experiences of male students aspiring to become professional elementary teachers through phenomenology as a research approach. It intends to contribute knowledge that would be generally useful in understanding why or why not males take the path of elementary teaching. If such an understanding should be comprehensive, it should start at the point where the elementary teaching journey begins, which is at the elementary teacher preparation stage.

\section{Methods}

This section outlines the research design, sample, instrument, procedure, and analysis employed to achieve the goal of this study. They are discussed as follows.

\subsection{Design}

A phenomenology is entailed as a design of this study. Smith (2007) defined phenomenology as a research approach that intends to describe the lived experience from the viewpoint of individuals who have encountered the phenomenon. Phenomenology does not discover causes; its purpose is to explain the phenomenon from the lived experience (Penner \& McClement, 2008). It is the lived experience that provides value to the perception of a group of people about a certain phenomenon, thus representing what is real to them (Giorgi, 1997). Aligned to the nature and purpose of phenomenology, the present research is carried out to capture the lived experience of the male students aspiring to become professional elementary teachers. 


\subsection{Sample}

As much as the researcher wanted to gather a larger pool of participants, however, the restrictions caused by the current situation made it difficult. At the end of the sampling process, only six male students participated, which is still adequate for the qualitative purpose of this research. Creswell (1998) proposed at least five participants while Morse (1994) recommended at least six participants for phenomenology. Moreover, in choosing the participants for phenomenology, the researcher used a criterion sampling technique, considering an important criterion (Palinkas et al., 2015) which in this case is the common experience to the phenomenon of being a male student aspiring to become a professional elementary teacher. Moser and Korstjens (2018) further suggested that, apart from the common experience on the phenomenon, the phenomenology research participants must differ in some characteristics to provide variation.

\begin{tabular}{ccccc}
\multicolumn{5}{c}{ Table-1. Participant Characteristics. } \\
\hline Participant & Age & Location & SHS track & Class section \\
\hline A & 21 & Urban & ICT & 1 \\
B & 20 & Rural & STEM & 2 \\
C & 20 & Urban & HUMMS & 2 \\
D & 19 & Urban & ICT & 1 \\
E & 20 & Rural & HUMMS & 2 \\
F & 21 & Urban & STEM & 1 \\
\hline
\end{tabular}

Table 1 shows the summary of the participant characteristics. Aside from the age, location, and section, the participants vary in the senior high school (SHS) track they finished: information and communication technology (ICT), humanities and social sciences (HUMMS), and science, technology, engineering, and mathematics (STEM).

\subsection{Context}

The male college students who served as participants of this study are currently enrolled in a predominantly female elementary teacher education program in a university in Mindanao, Philippines. Specifically, they came from two sections in a course handled by the researcher. The male to female ratio in the first section was 8:38 while in the second section was 10:44. These ratios show a somewhat underrepresentation of gender in a field of study as far as males are concerned in elementary teacher education.

\subsection{Instrument}

This study made use of an interview guide as a tool to collect the needed data for this study. It consisted of three main parts: overview, short survey of participant characteristics, and list of questions. Specifically, the last part contained questions to generate responses on the essence of being a male student aspiring to become a professional elementary teacher. These questions were content validated by an education professor and two male education students, who were not necessarily participants of this study. This measure was done to ensure the appropriateness of the tool.

\subsection{Procedure}

With the ongoing COVID-19 crisis, online modalities have been increasingly used for collecting qualitative data. An online modality is online interviews. According to Salmons (2015) online interviews can gather data synchronously or asynchronously, with text messages, video calls, or immersive spheres. Considering the structural difficulties of having unstable internet connectivity, this modality, mainly textbased, was employed in this study at some stages of the data collection process.

Before the interview proper, the researcher provided an overview of the study. It was stressed that their participation in this research is voluntary and confidential. It was also discussed that potential harm in the research process was minimal, but they were guaranteed that, if the process becomes disturbing, they may stop. After obtaining their consent, the research tool in Word file was sent to them through the Messenger chatbox. All of the participants answered the interview questions asynchronously. Then, the initial data generated were reviewed. During the next stage, the researcher arranged a time that is convenient with

International Journal of Educational
Studies
Volume 4, Issue 4, pp. 144-153
2021
DOI: 10.53935/2641-533x.v4i4.166
Email: mbcahapay@ up.edu.ph
Funding: This study received no specific
financial support.
Article History:
Received: 19 October 2021
Revised: 11 November 2021
Accepted: 2 December 2021
Published: 21 December 2021
(O 2021 by the authors; licensee Academic
Publishing Group

| 146 
selected participants for synchronous, text-based interviews through the Messenger chatbox. This procedure was conducted to further explore the initial responses that needed probes. The participants were asked to clarify or elaborate on certain points in their responses. After that, the additional data were reviewed. Then, all the data generated from the two stages were organized by the researcher in a master transcript.

\subsection{Analysis}

Once the data collection process was complete, the researcher began the data analysis. The researcher adopted the phenomenological data analysis framework of Moustakas (1994) to analyze the interview responses. This framework was observed in analyzing the data and presenting the results of this research as its rational process aligned with the purpose to understand the lived experiences of male students aspiring to become professional elementary teachers.

The researcher operationalized the data analysis framework through four stages as follows: 1.) identification of significant statements; 2.) classification of significant statements into themes; 3.) synthesis of themes into a description of experience; and 4.) formulation of the composite description of the experience. A process called member check was also performed by returning to the participants (Sanders, 2003). Member checking, also known as participant validation, is a technique for ensuring the credibility and trustworthiness of results by returning to participants to check for accuracy and resonance of their responses that represent their lived experience (Birt, Scott, Cavers, Campbell, \& Walter, 2016).

\section{Results}

The purpose of this study was to understand the lived experiences of the segment of male college students aspiring to become elementary teachers. The results are presented as follows.

Table-2. Identification of Significant Statements.

Sample of Significant Statements
"I felt intimidated by the fact that I have more female classmates than male classmates. At
first, it was hard to adjust to dealing with female classmates because I used to have more
male classmates."
"Watching documentaries about the situation of children in isolated areas that are
extremely lacking educational support affected me. I felt pity for them knowing that
education is a right."
"Actually, there are stereotypes. One time my mother said that most of her male
acquaintances in education seem feminine. So, many people think that males who are into
teaching are feminine."
"As a male student in elementary teacher education, I feel connected. The department
welcomes me and makes me feel I belong. I do well with my classmates. They are helpful
and do not treat me differently because I am a male."
"When some of my relatives knew that I am taking up elementary teacher education, their
usual response to me was 'you will not get rich in that profession.' Though it does not
really affect me"
"The department is something cool. The senior students are friendly to us. Most of the
faculty members are helpful. I love the activities during freshmen night, general
assemblies, and other events where I can show my skills."
"At first, I felt a little bit embarrassed because, in our class, I observed that there were
more females than males. It felt very awkward to me. I found it initially hard to myself to
approach them."
"This department is not just a department itself but a family. We have dedicated instructors
that holistically train us. This department makes us feel like we are valued members. Its
relationship with us is supportive and nurturing."
"I received doubtful and negative comments like 'why do you want to become a teacher?'
or 'it pays a little.' Then, other people also would say 'are you sure about it?' and add 'it is
a demanding work.'."
"During our high school work immersion, at first, dealing with young children is very
hard. As the time went by, I was slowly hooked with the work because dealing with young
ones is actually very fun and fulfilling."
+ 24 other significant statements

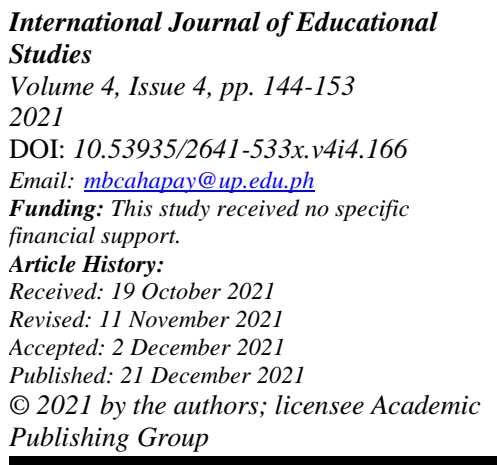




\section{Stage 1: Identification of Significant Statements in the Transcript}

The initial phase in the analysis is the process called horizonalization. The significant statements that provide information regarding the lived experience of interest to the research are identified in the transcripts. These significant statements are presented for the reader to glean the range of perspectives about the phenomenon. Table 2 presents the sample of these significant statements.

This preliminary stage identified a total of 36 significant statements. The result of this procedure is represented by the samples as displayed above. They are an individual extrapolation from the transcripts. There is no deliberate act to group them or sequence them. The researcher only presented how the male college students perceived their experience as aspiring to become professional elementary teachers.

\section{Stage 2: Classification of Significant Statements into Themes}

The second stage in the analysis carefully examined the remaining significant statements and clustered them into meaning units or themes. These themes are shared in the significant statements of the participants about their experience as male college students aspiring to become professional elementary teachers. Table 3 presents the sample of significant statements and emergent themes.

Table-3. Classification of Significant Statements into Themes.

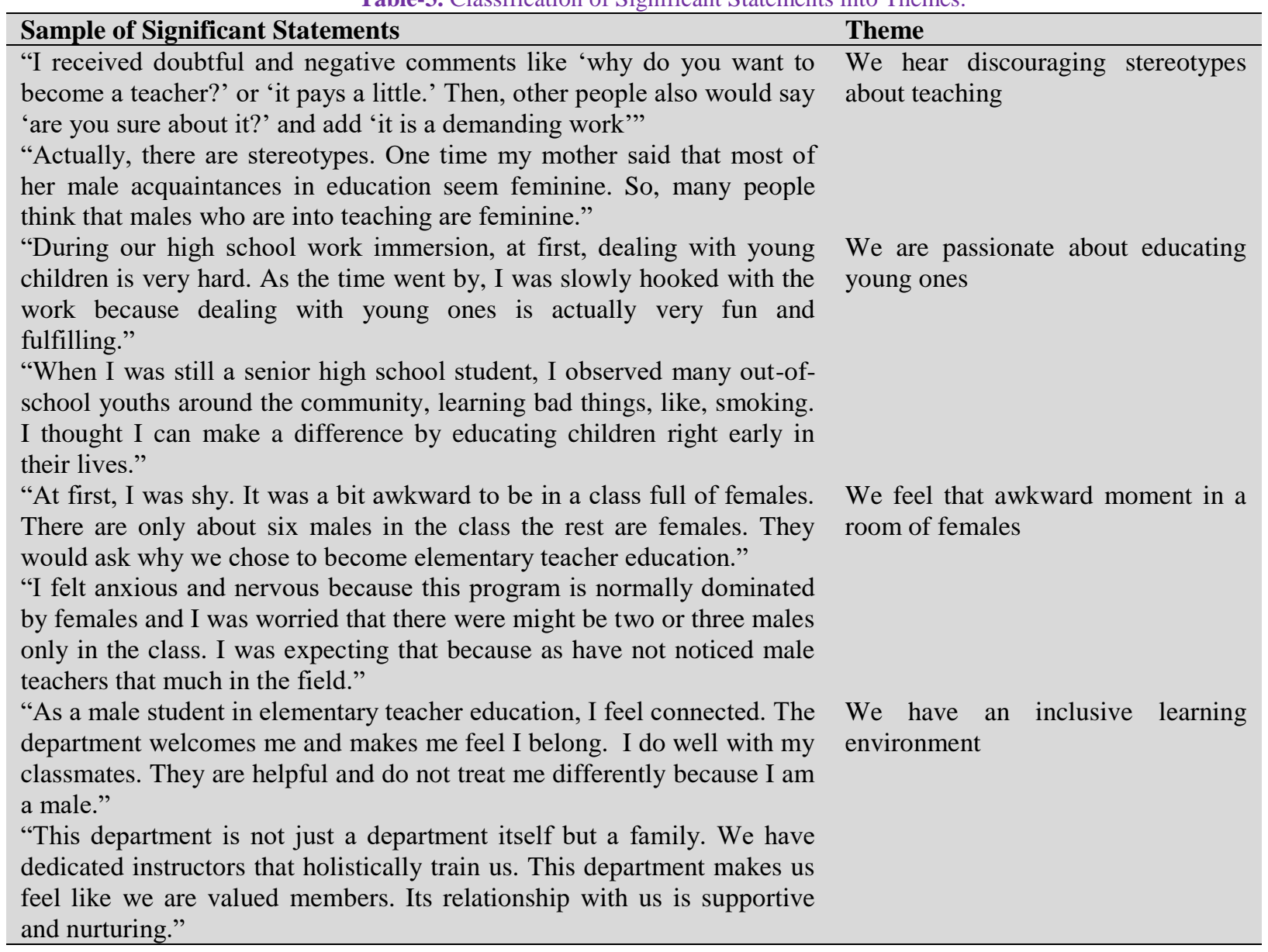

International Journal of Educational Studies

Volume 4, Issue 4, pp. 144-153

2021

DOI: $10.53935 / 2641-533 x . v 4 i 4.166$

Email: mbcahapay@up.edu.ph

Funding: This study received no specific

financial support.

Article History:

Received: 19 October 2021

Revised: 11 November 2021

Accepted: 2 December 2021

Published: 21 December 2021

(C) 2021 by the authors: licensee Academic

Publishing Group

Four themes emerged in the analysis of the significant statements across the participants. These themes are 1.) We hear discouraging stereotypes about teaching; 2.) We are passionate about educating the young ones; 3.) We feel that awkward moment in a room of females; and 4.) We have an inclusive learning environment. They are discussed in the next stage.

\section{Stage 3: Synthesis of Themes into Description of Experience}

At this stage, the researcher integrated all the significant statements and themes into a full description of the phenomenon. This full description is presented as a narrative report and reflects all the dimensions of the 
lived experience of male college students aspiring to become professional elementary teachers. The themes, meanings, and statements are discussed below:

Theme 1: We hear discouraging stereotypes about teaching. A consistent statement in the narratives of the participants is the discouraging stereotypes that they encountered throughout their formative and formal journey to becoming professional elementary teachers. These stereotypes range from occupation- and genderbased, giving misjudgments about elementary teaching. These remarks, mostly unfavorable, were shared by the participants as follows:

"There were dissuasions that were said to me back then. They said, 'do not take up elementary teaching, it will not help you grow, you will be stagnant, you will not be challenged with children,' things like those" -Participant C.

"Actually, there are stereotypes. One time my mother said that most of her male acquaintances in education seem feminine. So, many people think that males who are into teaching are feminine" Participant D.

"When some of my relatives knew that I am taking up elementary teacher education, their usual response to me was 'you will not get rich in that profession.' Though it does not really affect me" Participant E.

Theme 2: We are passionate about educating young ones. Despite the diverse interests, different aspirations, and negative stereotypes, what made the participants remain in the field of elementary teacher education is their common passion for educating the young. This passion stems from the positive educational experiences that the participants acquired and learned early in their lives through different people and events. This theme is consistent in the responses of the participants as mirrored in their responses as follows:

"During our high school work immersion, at first, dealing with young children is very hard. As the time went by, I was slowly hooked with the work because dealing with young ones is actually very fun and fulfilling" -Participant A.

"Watching documentaries about the situation of children in isolated areas that are extremely lacking educational support affected me. I felt pity for them knowing that education is a right" Participant E.

"When I was still a senior high school student, I observed many out-of-school youths around the community, learning bad things, like, smoking. I thought I can make a difference by educating children right early in their lives" -Participant F.

Theme 3: We feel that awkward moment in a room of females. Another recurring idea shared across the statements of the participants is the 'awkward moment' characterized by a feeling of being mostly uncomfortable, that they experienced during the first days of their classes as college students enrolled in an elementary education program. They ascribe this emotion knowing that they were surrounded by mostly females in their classes. The participants shared that:

"At first, I felt a little bit embarrassed because, in our class, I observed that there were more females than males. It felt very awkward to me. I found it initially hard to myself to approach them" -Participant A.

"At first, I was shy. It was a bit awkward to be in a class full of females. There are only about six males in the class the rest are females. They would ask why we chose to become elementary teacher education" -Participant D.

"I felt intimidated by the fact that I have more female classmates than male classmates. At first, it was hard to adjust to dealing with female classmates because I used to have more male classmates" -Participant F.

Theme 4: We have an inclusive learning environment. Despite the issues experienced by the participants, they intended to remain and persist in studying elementary teacher education mainly because of the encouraging learning environment they received from the department and the people within it. It should be particularly noted that such an environment does not detach students based on socially organized groups, making interactions more fluid than gendered. It is the emotional valuing, regardless of genders, that makes males continue in a female-dominated sphere. These sentiments are reflected by the participants as follows:

"This department is not just a department itself but a family. We have dedicated instructors that holistically train us. This department makes us feel like we are valued members. Its relationship with us is supportive and nurturing" -Participant B. 
"The department is something cool. The senior students are friendly to us. Most of the faculty members are helpful. I love the activities during freshmen night, general assemblies, and other events where I can show my skills" -Participant C.

"As a male student in elementary teacher education, I feel connected. The department welcomes me and makes me feel I belong. I do well with my classmates. They are helpful and do not treat me differently because I am a male" -Participant D.

\section{Stage 4: Formulation of Composite Description of Experience}

Once the themes, meanings, and statements have been synthesized, the researcher performed a process of imaginative variation to develop the composite description of the experience. This process discusses what and how the participants collectively experienced being male students in the elementary teacher education program. The composite description is presented as follows:

"The experience of the male students aspiring to become a professional elementary teacher is characterized by interesting points. They have socially heard several gender- and occupation-based stereotypes about education and elementary teaching. However, their positive early experiences shaped their passion for teaching the young ones which eventually guided them to foray into the field of elementary teacher education program. The male students live out their initial experience in the formal elementary teacher education program as characterized by an awkward moment because of the presence of a large majority of females in their classes. But they are quite motivated to remain and continue in the elementary teacher education program because of the inclusive environment provided to them by their peers, classmates, teachers, and the program as a whole."

\section{Discussion}

This phenomenology research is anchored on the purpose of exploring how male college students live out their experience as they aspire to become professional elementary teachers, a role that has been traditionally perceived as atypical for males. This paper uncovered five emergent themes that underlie the essence of the individual and composite descriptions of the phenomenon under investigation. They are discussed as follows.

Theme 1 expresses "We hear discouraging stereotypes about teaching." These stereotypes have been reported by scholars and male teachers in the field. There have been issues negatively attributed to male teachers and elementary teaching such as sexual orientation and suitability for the work (Henry, 2012; Johnson, Middleton, Nicholson, \& Sandrick, 2010) stereotypical gender models and assumptions about the education of the young (Bianco, Leech, \& Mitchell, 2011; Huang, 2007; Sargent, 2001) and low social status and salary as compared to other occupations (Carrington, 2002; Skelton, 2003). These stereotypes reflect the prevalent negative perceptions of society towards teaching as a profession, which in turn, may be disabling factors for males to decide to enter or persist in elementary teacher preparation programs (Cushman, 2005).

Moreover, theme 2 is "We are passionate about educating the young ones." Studies point that the reasons that lead men to choose careers in teaching are generally similar to women. One of these known reasons refers to the noble aspects of teaching such as contributing to society, helping children develop, and sharing knowledge (Han, Borgonovi, \& Guerriero, 2020; Richardson, 2011; Thornton, Bricheno, \& Reid, 2002). Focusing on the males, Keck, Berweger, and Bieri (2017) found out that an interest in dealing with children and having encounters working with children add to the chance of males deciding to take up a teacher education program. Consistent with this study, Sanatullova-Allison (2010) elaborated that the factors that influence males to decide to take the field of elementary education exemplify a spectrum from personal experiences to the vocational influence of people around.

Theme 3 tells "We feel that awkward moment in a room of females." At least within the teaching career stage, males reported that working in an environment dominated by females made them feel a sense of social isolation especially when there was no male colleague to interact with Skelton (2003). Moreover, based on a review of related works, Rice and Goessling (2005) supported that one factor that contributes to the gap between males and females entering education as a career is the few male peers. He further explained the unspoken sense that elementary schools are social places for females to exert dominance. Putting this situation in the context of the teacher preparation stage, this reason could also explain why males feel awkward in their classes where they are a minority in number and females form the noticeably large majority.

Lastly, theme 4 is "We have an inclusive learning environment." Drawing from scholarly works and 
professional experience in the field, Patrick (2005) advised that, to retain males in teacher education programs, schools should create encouraging opportunities such as gathering male students or matching them to male advisors and cooperating teachers. It should be highlighted, however, that in this study, none of the male students specifically pointed out "gendered" strategies that contributed to their motivation to stay in the program. It was the inclusive interactions with their classmates, seniors, and instructors regardless of gender that made them feel they belong to the elementary teaching program. This implies that the social and emotional acceptance of males in a traditionally female field of study is a powerful factor that may be taken to the advantage of attracting and retaining males in the elementary teacher education program.

\section{Conclusion}

Despite the equal access that has been given to both genders, there remains a minority group of males pursuing elementary teacher education. On the other note, minimal research has been conducted to explore how male college students live out their experience in elementary teacher education programs. Thus, this phenomenology research aimed to understand the lived experiences of the male college students aspiring to become professional elementary teachers. The following themes emerged: 1.) We hear discouraging stereotypes about teaching; 2.) We are passionate about educating the young ones; 3.) We feel that awkward moment in a room of females; and 4.) We have an inclusive learning environment. These themes are based on the individual textural and structural descriptions and form the basis for the composite textural and structural descriptions of the lived experiences of male students aspiring to become professional elementary teachers.

This paper contributes knowledge to gender studies. It confirms the first-hand experiences encountered by males in the formal teaching career stage as relative to the second-hand experiences received by males in the early stage of the teacher preparation. It also provides that notion of an awkward moment in the initial point of the teacher preparation stage where males feel a need to adjust in a program noticeably dominated by females. Moreover, this paper offers several practical insights that may be useful in the field of elementary teacher education. It identifies several factors that encourage males to enter the elementary teacher education program. Many of these factors, however, are societal and cannot be easily changed. A lesson that can be learned from this study for the elementary teacher education program is the conscious effort for inclusive socialization as a strategy to create an encouraging learning environment that increases the sense of belongingness of the male students to the program. This strategy may be conducted especially at the beginning of the school year when major adjustments occur and from time to time in group activity assignments and student internship placements e.g., peers, supervising teachers, cooperating teachers.

Furthermore, the results of this study should be carefully interpreted as far as the context of this study is concerned. While the sample guideline for phenomenology was observed, there is a need to involve more participants to further saturate the data. It should be noted also that the participants came from two sections and one-year level only, thus maximum variation may not have been achieved. Other methods such as focus group discussions and observations may also be needed to improve the validity of the results drawn in this study. Building on these essential points, researchers in the field are encouraged to replicate this study in other contexts.

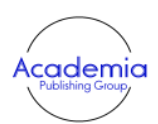

International Journal of Educational Studies

Volume 4, Issue 4, pp. 144-153

2021

DOI: $10.53935 / 2641-533 x . v 4 i 4.166$

Email:mbcahapay@up.edu.ph

Funding: This study received no specific

financial support.

Article History:

Received: 19 October 2021

Revised: 11 November 2021

Accepted: 2 December 2021

Published: 21 December 2021

(C) 2021 by the authors: licensee Academic

Publishing Group

\section{References}

Anjum, G., Kamal, A., \& Bilwani, S. (2019). Antecedents of gender gap in workforce participation: A phenomenology of psychologists and medical doctors in urban Pakistan. Journal of Human Behavior in the Social Environment, 29(2), $282-299$. Available at: https://doi.org/10.1080/10911359.2018.1536576.

Baunach, D. M. (2002). Trends in occupational sex segregation and inequality, 1950 to 1990. Social Science Research, 31(1), 77-98. Available at: https://doi.org/10.1006/ssre.2001.0719.

Bianco, M., Leech, N. L., \& Mitchell, K. (2011). Pathways to teaching: African American male teens explore teaching as a career. The Journal of Negro Education, 80(3), 368-383.

Birt, L., Scott, S., Cavers, D., Campbell, C., \& Walter, F. (2016). Member checking: A tool to enhance trustworthiness or merely a nod to validation? Qualitative Health Research, 26(13), 1802-1811. Available at: https://doi.org/10.1177/1049732316654870.

Bittner, M., \& Cooney, M. (2001). Men in early childhood education: Their emergent issues. Early Childhood Education Journal, $29(2), 77-82$

Bongco, R. T., \& Abenes, R. D. (2019). Clash of spheres - the paradox of being a female teacher in the Philippines. Beijing International Review of Education, 1(2-3), 443-459. Available at: https://doi.org/10.1163/25902539-00102012.

Carrington, B. (2002). A quintessentially feminine domain? Student teachers' constructions of primary teaching as a career. Educational Studies, 28(3), 287-303. Available at: https://doi.org/10.1080/0305569022000003735. 
Creswell, J. W. (1998). Qualitative inquiry and research design: Choosing among five traditions. Thousand Oaks, CA: Sage Publications.

Cushman, P. (2005). Let's hear it from the males: Issues facing male primary school teachers. Teaching and Teacher Education, 21(3), 227-240. Available at: https://doi.org/10.1016/j.tate.2005.01.012.

Cushman, P. (2006). Wanted! Male teachers. The extent to which principals want and encourage a gender balance on school staff. Paper presented at the British Educational Research Association Annual Conference.

Drudy, S. (2008). Gender balance/gender bias: The teaching profession and the impact of feminisation. Gender \& Education, 20(4), 309-323. Available at: https://doi.org/10.1080/09540250802190156.

Flores, M. A., \& Day, C. (2006). Contexts which shape and reshape new teachers' identities: A multi-perspective study. Teaching and Teacher Education, 22(2), 219-232. Available at: https://doi.org/10.1016/j.tate.2005.09.002.

Garcia, R. M. (2014). Educator perceptions: The impact of male elementary school teachers. Doctoral Dissertation, California State University, Monterey Bay.

Giorgi, A. (1997). The theory, practice, and evaluation of the phenomenological method as a qualitative research procedure. Phenomenological Psychology, 28(2), 235-260. Available at: https://doi.org/10.1163/156916297x00103.

Greger, S. V. (2014). Male teachers in elementary general music. Retrieved from https://dc.uwm.edu/etd/579.

Han, S. W., Borgonovi, F., \& Guerriero, S. (2020). Why don't more boys want to become teachers? The effect of a gendered profession on students' career expectations. International Journal of Educational Research, 103, 101645. Available at: https://doi.org/10.1016/j.ijer.2020.101645.

Henry, S. K. (2012). Experiences of male teachers in the elementary grades. Honors Project, Rhode Island College.

Huang, Q. (2007). Male Kindergarten teachers' entering and adapting to early childhood education. M.A. Thesis. WanFang Data.

International Labor Organization. (2008). Module on gender, poverty and employment. Geneva, Switzerland: ILO International Training Centre.

Johnson, S. P., Middleton, R., Nicholson, N., \& Sandrick, D. (2010). Still so few male teachers. Young Children, 65(3), 18-23.

Keck, F. A., Berweger, S., \& Bieri, B. C. (2017). Men considering (and choosing) teaching as a career: What accounts for their decision to become a teacher? European Journal of Teacher Education, 40(4), 535-549. Available at: https://doi.org/10.1080/02619768.2017.1315397.

Levin, B., \& He, Y. (2008). Investigating the content and sources of teacher candidates' personal practical theories (PPTs). Journal of Teacher Education, 59(1), 55-68. Available at: https://doi.org/10.1177/0022487107310749.

Makarova, E., Aeschlimann, B., \& Herzog, W. (2019). The gender gap in STEM fields: The impact of the gender stereotype of math and science on secondary students' career aspirations. Frontiers in Education, 4, 60. Available at: https://doi.org/10.3389/feduc.2019.00060.

Meader, K. (2017). A shortage of male elementary school teachers: Exploring the perceptions of male teachers using $Q$ methodology. Doctoral Dissertation.

Morse, J. M. (1994). Designing funded qualitative research. In Denizin, N. K. \& Lincoln, Y. S., Handbook of qualitative research (2nd ed.). Thousand Oaks, CA: Sage.

Moser, A., \& Korstjens, I. (2018). Series: Practical guidance to qualitative research. Part 3: Sampling, data collection and analysis. European Journal of General Practice, 24(1), 9-18. Available at: https://doi.org/10.1080/13814788.2017.1375091.

Moustakas, C. (1994). Phenomenological research methods. Thousand Oaks, CA: Sage.

Palinkas, L. A., Horwitz, S. M., Green, C. A., Wisdom, J. P., Duan, N., \& Hoagwood, K. (2015). Purposeful sampling for qualitative data collection and analysis in mixed method implementation research. Administration and Policy in Mental Health and Mental Health Services Research, 42(5), 533-544. Available at: https://doi.org/10.1007/s10488-013-0528-y.

Patrick, M. (2005). Addressing the lack of male elementary school teachers: Factors that influence grade- level preference. Retrieved from https://eric.ed.gov/?id=ED531490.

Penner, J., L., \& McClement, S. E. (2008). Using phenomenology to examine the experiences of family caregivers of patients with advanced head and neck cancer: Reflections of a novice researcher. International Journal of Qualitative Methods, 7(2), 92101. Available at: https://doi.org/10.1177/160940690800700206.

Powers, K., Herron, E. K., Sheeler, C., \& Sain, A. (2018). The lived experience of being a male nursing student: Implications for student retention and success. Journal of Professional Nursing: Official Journal of the American Association of Colleges of Nursing, 34(6), 475-482. Available at: https://doi.org/10.1016/j.profnurs.2018.04.002.

Regalado, M. (2017). Career mobility and gender: A descriptive study of selected deped teachers in Iligan City. In S. Aimimtham \& A. Nurmandi, The Complexity of Managing Local Government in Selected ASEAN Countries. Yogyakarta, Indonesia: Asia Pacific Society for Public Affairs.

Reskin, B. F. (2001). Sex segregation at work. International Encyclopedia of the Social \& Behavioral Sciences, 13962-13965. Available at: https://doi.org/10.1016/b0-08-043076-7/03994-2.

International Journal of Educational Studies

Volume 4, Issue 4, pp. 144-153

202

DOI: $10.53935 / 2641-533 x . v 4 i 4.166$

Email: mbcahapay@up.edu.ph

Funding: This study received no specific

financial support.

Article History:

Received: 19 October 202

Revised: 11 November 2021

Accepted: 2 December 2021

Published: 21 December 202

(C) 2021 by the authors: licensee Academic

Publishing Group

Rice, C. J., \& Goessling, D. P. (2005). Recruiting and retaining male special education teachers. Remedial and Special Education, 26(6), 347-356. Available at: https://doi.org/10.1177/07419325050260060501.

Richardson, A. N. (2011). A phenomenological inquiry into the unique experience of male elementary teachers. Retrieved from https://pqdtopen.proquest.com/pubnum/3620787.html.

Salmons, J. (2015). Qualitative online interviews (2nd ed.). London: Sage.

Sanatullova-Allison, E. (2010). Why men become elementary school teachers: Insights from an elementary teacher education program. Action in Teacher Education, 31(4), 28-40. Available at: https://doi.org/10.1080/01626620.2010.10463533.

Sanders, C. (2003). Application of Colaizzi's method: Interpretation of an auditable decision trail by a novice researcher. Contemporary Nurse, 14(3), 292-302. Available at: https://doi.org/10.5172/conu.14.3.292.

Sargent, P. (2001). Real men or real teachers? Harriman: Men's Studies Press. 
Schmude, J., \& Jackisch, S. (2019). Feminization of teaching: Female teachers at primary and lower secondary schools in badenWürttemberg, Germany: From its beginnings to the present. Geographies of Schooling, 333-349. Available at: https://doi.org/10.1007/978-3-030-18799-6_17.

Schurman, N. J. (2015). Caught in the middle: Understanding the experiences of men elementary school teachers. Dorctoral Dissertation, University of St. Thomas.

Shouldice, H. (2013). Trading hindemith for "hugs, high-fives, and handshakes": One preservice music teacher's decision to teach elementary general music. Bulletin of the Council for Research In Music Education, 195, 41-57. Available at: https://doi.org/10.5406/bulcouresmusedu.195.0041.

Skelton, C. (2003). Male primary teachers and perceptions of masculinity. Educational Review, 55(2), 195-209. Available at: https://doi.org/10.1080/0013191032000072227

Smith, D. W. (2007). Husserl. New York: Routledge.

Thornton, M., Bricheno, P., \& Reid, I. (2002). Students' reasons for wanting to teach in primary school. Research in Education, 67(1), 33-43. Available at: https://doi.org/10.7227/rie.67.4.

Walker, L. C. (2012). African American male elementary teachers' perceptions on factors that influence their retention and attrition: A qualitative study. Dorctoral Dissertation, University of Southern Mississippi.

Williams, C. L. (1992). The glass escalator: Hidden advantages for men in the "female" professions. Social Problems, 39(3), $253-267$. Available at: https://doi.org/10.1525/sp.1992.39.3.03x0034h.

\author{
International Journal of Educational \\ Studies \\ Volume 4, Issue 4, pp. 144-153 \\ 2021 \\ DOI: $10.53935 / 2641-533 x . v 4 i 4.166$ \\ Email: mbcahapay@up.edu.ph \\ Funding: This study received no specific \\ financial support. \\ Article History: \\ Received: 19 October 2021 \\ Revised: 11 November 2021 \\ Accepted: 2 December 2021 \\ Published: 21 December 2021 \\ (c) 2021 by the authors; licensee Academic \\ Publishing Group
}

Williams, K. (2012). A phenomenological study: African-American males in the educational profession. Retrieved from
https://digitalcommons.liberty.edu/cgi/viewcontent.cgi?article=1528\&context=doctoral.

Williams, K. (2012). A phenomenological study: African-American males in the educational profession. Retrieved from
https://digitalcommons.liberty.edu/cgi/viewcontent.cgi?article=1528\&context=doctoral. 